\title{
The Demise of the County \\ Courthouse Tower in Iowa: \\ A Study of Early Twentieth-Century \\ Cultural and Architectural Change
}

\section{WESLEY IVAN SHANK}

COUNTY COURTHOUSES are architectural landmarks on the Iowa landscape, especially in its smaller towns. With their high towers rising at the middle or at a corner of the main facade or emerging from the center of the roof, many nineteenth-century courthouses were visible from the distant prairie. A clock, bells, or the traditional statue of Justice often embellish these ornamental towers. Inside, some of the late nineteenth-century courthouses included a well or an atrium two or more stories high and lighted by a skylight.

The tall ornamental tower had become a characteristic feature of Iowa courthouses by the last third of the nineteenth century. Yet none of the Iowa courthouses built after 1909 had such a tower. Such a major change is surprising, especially since it did not accompany the adoption of a new architectural style. Among Iowa courthouses built from 1900 to 1902, the American Renaissance style replaced the Romanesque Revival styles that had characterized the late nineteenth-century courthouses. The American Renaissance prevailed, with one excep-

To John Cunnally, Jeoraldean McClain, and Gary Tartakov of the College of Design at Iowa State University and to Ralph Christian, Judy McClure, and Lowell Soike of the State Historical Society of Iowa in Des Moines, who read an earlier version of this study, my gratitude for their suggestions. To the Department of Architecture at Iowa State University, my gratitude for underwriting the cost of the illustrations.

THE ANNALS OF IOWA 51 (Spring 1992). CThe State Historical Society of Iowa, 1992. 
tion, until the Art Deco style replaced it in 1928 and $1929 .{ }^{1}$ The exception-the Prairie-style Woodbury County Courthouse in Sioux City (1916) - is also the only Iowa courthouse built after 1909 to display a tower, but its tower is functional, not ornamental. Until 1909, courthouses built in the American Renaissance style continued to include towers, but after 1909 none of them did. Accompanying this change was an increasing use of wells and atriums inside the courthouses.

This architectural development was associated with significant changes in the governmental functions of county courthouses in the early part of the twentieth century, and was the result of local and regional decisions made by designers and their clients; it was not merely a provincial manifestation of avant-garde architectural ideas. Whatever the causes and context, histories and descriptions of individual courthouses built in Iowa in the first three decades of the twentieth century reveal that within the American Renaissance style, a new courthouse type had developed in Iowa by 1915 .

THE DEMISE of the county courthouse tower did not, as one might anticipate, reflect a decline in the importance of county courthouses. Instead, two types of governmental changes were actually adding to the importance of county courthouses. These buildings were important in the nineteenth century as the seat of the form of government closest to the lives of Iowa's largely rural population. Courthouse towers visibly attested to the importance of these buildings as temples of justice. As the urban population grew, counties declined in importance compared to cities, but at the same time they came to be used more and more as agents for state government. Thus, the activities of county government increased with the increase in the activities of state government. These new functions were largely admin-

1. The date when construction started is usually the most useful date, as it best represents the date of the completed design. Minutes of county boards of supervisors' meetings, local newspapers, county histories, cornerstones and building plaques, and my visits to all of the extant buildings and photographs of them supplied most of the information. LeRoy Pratt, The Counties and Courthouses of Iowa (Mason City, 1977), and Edward Stanek and Jacqueline Stanek, Iowa's Magnificent County Courthouses (Des Moines, 1976), were also consulted. 
istrative. County government took on a growing number of bureaucratic functions alongside the solemn responsibilities of meting out justice, which had been the principal activity in earlier courthouses. During the first decades of the twentieth century, the courthouses became places where county residents came to obtain licenses, pay fees and taxes, and conduct other ordinary business with their county government and with their state government for which the county was the local agent. ${ }^{2}$

Americans' attitudes toward the role of government changed during these times. The beginning of the twentieth century brought prosperity for America's middle class, especially for its farmers. The period from 1900 to 1920 has been called the golden age of American agriculture. It seemed that "justice and prosperity for all was attainable through good will and progressive legislation." As part of the Progressive movement, which was especially strong in the Middle West, government was reformed at all levels and adapted to changes in American society, taking advantage of the organizational skills developed by American business in the period of post-Civil War industrialization. Progressives rejected the notion that justice could be achieved solely through the actions of individuals; justice, they believed, required governmental action. The values of the small town were replaced by those of a bureaucratic middle class-values of "continuity and regularity, functionality and rationality, administration and management" that were needed to cope with the problems of the twentieth century. ${ }^{3}$

At the same time, American architects were turning to the American Renaissance style of architecture. That style was widely used from about 1880 to 1930 in the United States, especially for public buildings. A building in that eclectic style typically combined decorative features freely selected from Roman imperial architecture, the Italian Renaissance and the

2. Benjamin F. Shambaugh, ed., County Government and Administration in Iowa (Iowa City, 1925), 2, 20, 24, 35.

3. Harold D. Guinther, Heritage of Plenty: A Guide to the Economic History and Development of American Agriculture (Danville, IL, 1972), 102; Samuel Eliot Morison, The Oxford History of the American People (New York, 1965), 812, 815, 841; Robert H. Wiebe, The Search for Order, 1877-1920 (New York, 1966), vii, viii. 
French and English architecture that stemmed from it, and later American colonial architecture. These architectural features reflected their designers' scholarly knowledge of historic architecture, and the design of each building as a whole reflected the grand manner of the French École des Beaux-Arts. The American Renaissance style, with the variety of its eclectic features referring to the greatness of many historic civilizations, reflected an American national identity in which the country was seen as the "culmination of history for an age that believed in progress." The country's public buildings manifested that civilization, and thus were of primary importance. Furthermore, since the style was rational and orderly, it was a consistent expression of the search for order that was characteristic of the times. ${ }^{4}$

The American Renaissance style developed within a broader architectural context set forth by architectural historian Carroll L. V. Meeks. He designated all of the architecture of the period from 1790 to 1914 as Picturesque Eclecticism, which he divided into three phases. During the middle phase, Synthetic Eclecticism (1860-1890), buildings combined architectural elements from several historical styles. They sought verticality, as seen in the use of towers and well-like interior spaces. A jagged roof silhouette was typical. The Romanesque Revival courthouses of Iowa are examples, as are its American Renaissance courthouses with towers, even though in Iowa the last of these dates from 1909. Meeks's final phase was Creative Eclecticism (1890-1914). Designs in this phase combined historic elements more freely than literally. They valued honest expression of purpose and use of appropriate materials. They sought a simple and comprehensible design. Finally, they rejected the vertical lines and the jagged roof silhouette of the middle phase in favor of horizontal lines and a simple "subsiding" outline. ${ }^{5}$

4. The Brooklyn Museum, The American Renaissance, 1876-1917 (New York, 1979), 11-15, 57; Spiro Kostof, A History of Architecture: Settings and Rituals (New York, 1985), 683. I have chosen the designation American Renaissance because these buildings are so freely eclectic. I intend it to include both the Beaux Arts and the Classical Revival styles as designated by John C. Poppeliers, S. Allen Chambers, Jr., and Nancy B. Schwartz in their authoritative book, What Style Is It? (Washington, 1983).

5. Carroll L. V. Meeks, The Railroad Station: An Architectural History (New 
Architectural history is more than the history of the manifestation of avant-garde architectural theories and designs, however. Built architecture always has a particular geographic location. Although architectural history reflects the influence of great and successful architects, it is also shaped by particular local architectural traditions. The architectural firms commissioned for the Iowa courthouses built in the early decades of the twentieth century were of two sorts. Those of regional reputation, practicing in several states, were usually closer to avantgarde architectural trends, as one can see in their designs for courthouses in Iowa's more populous counties-Webster, Black Hawk, Polk, Woodbury, and Linn. Generally, the architects who designed the courthouses in the less populous counties were of local reputation, and their designs were generally less innovative stylistically. Both types of architects had to respond to the shared common values of the people of Iowa. The county governments who hired them likewise shared characteristics mandated by the state government that created them.

Built architecture is also the product of an interaction between architect and client. Broadly speaking, it is the result of an adjustment between what the architect proposes and what the client accepts. As client, a county board of supervisors often began to interact with architects in the process of design after the voters had approved issuing bonds for a new courthouse. A board advertised that it would consider architects' plans and specifications for a new courthouse, giving the estimated price, and would spend several days interviewing architects and studying the preliminary plans and specifications that the architects brought with them. Then the board would select the architect whose designs best suited their needs, preferences, and budget.

For example, a large number of architects participated in an architectural competition sponsored by the Crawford County supervisors in 1903. The supervisors then selected an architect based on the plans submitted. After the construction contract was let, the supervisors considered reducing the cost of the building by eliminating the tower, substituting brick for the

Haven, CT, 1956), 3, 13, 17, 24. His focus on one building use-type is interesting. 
limestone exterior walls, and omitting the marble wainscot inside, although none of these measures had to be taken. ${ }^{6}$ The fact that the building was not cheapened by these reductions attests to its symbolic importance to county citizens, for the reductions would not have interfered with the utilitarian functions of the building.

The Harrison County supervisors spent two-and-a-half days in February 1910 interviewing twelve architects and examining courthouse plans. After narrowing the contestants to five, the supervisors examined buildings designed by these five before choosing their architect the following month. Neither the supervisors' minutes nor the local newspaper record what anyone thought about the buildings proposed by the twelve architects interviewed or about the building that was built; the newspaper does not even describe it, other than merely mentioning the dome in connection with the dedication ceremonies. A county history lists the quantities of each building material used, probably to impress the citizens with how much they got for their money. ${ }^{7}$

The interaction between the board of supervisors and architects took a different turn in the case of Lyon County. Architect W. R. Bell of Minneapolis went so far as to prepare courthouse plans for the board of supervisors immediately after the voters approved the bond issue in 1914. His taking the initiative did not get him the commission, however. Three of the supervisors' terms expired, and they did not want to commit their successors. It appears that the new board chose from among several architects interviewed in 1915 based on the fees the architects requested, their experience, and how close their office was to the county seat. Joseph Schwartz of Sioux Falls, South Dakota, was chosen and then submitted preliminary plans. $^{8}$

6. F. W. Meyers, History of Crawford County, Iowa, 2 vols. (Chicago, 1911), $1: 221,222$.

7. Harrison County Minute Book, vol. 7, pp. 251, 252, 256; Logan Gazette, 9 November 1911; Charles W. Hunt and Will L. Clark, History of Harrison County, Iowa (Indianapolis, 1915), 103.

8. Paul Smith and Lucy Jo Colby, Buncombe to "Twenty Two (Rock Rapids, 1975), 196-97; Rock Rapids Review, 15 April 1915. 


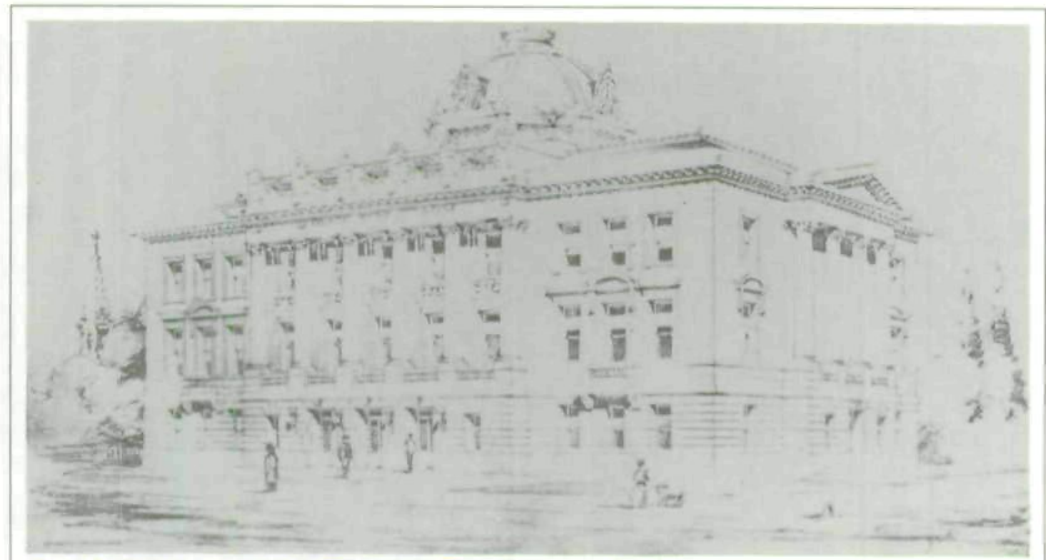

Fig. 1. Black Hawk County Courthouse, Waterloo, one of three similar designs proposed by H. C. Koch \& Co., 1901. Illustration from Architectural Review (Boston), 9 April 1902, plate xvii.

Two cases of rejected courthouse designs are of special importance for this investigation. If the Black Hawk County supervisors' had not rejected all three of H. C. Koch's proposed domed courthouse designs in 1901 (fig. 1), the demise of the courthouse tower in Iowa would have begun eight years earlier. Judging by the elaborate carved stonework of Koch's designs, they would have been more expensive than F. D. Orff's, with its domed tower, which was built. ${ }^{9}$ The Linn County supervisors' rejection of the optional tower of J. W. Royer's 1920 courthouse design (fig. 9), on the other hand, helped ensure the absence of towers from later courthouses in Iowa. In response to Royer's designs, the supervisors assumed the option to make changes as they wished, including changes affecting the height of the tower. ${ }^{10}$

In every case, one would like to know more about what the supervisors thought about the designs they reviewed, but neither local newspapers nor official records reveal that sort of information unless it relates to a matter of law or economy. We

9. Koch published three domed designs for this building. See Architectural Review (Boston) 9 (April 1902), plates xv, xvi, xvii. He did not receive the commission. For an illustration of Orff's design, see Isaiah Van Metre, History of Black Hawk County, Iowa, and Representative Citizens (Chicago, 1904), 36.

10. Cedar Rapids Evening Gazette, 23 October 1920; Proceedings of the Board of Supervisors of Linn County, 1918-1923, pp. 202, 203, 319, 340. 


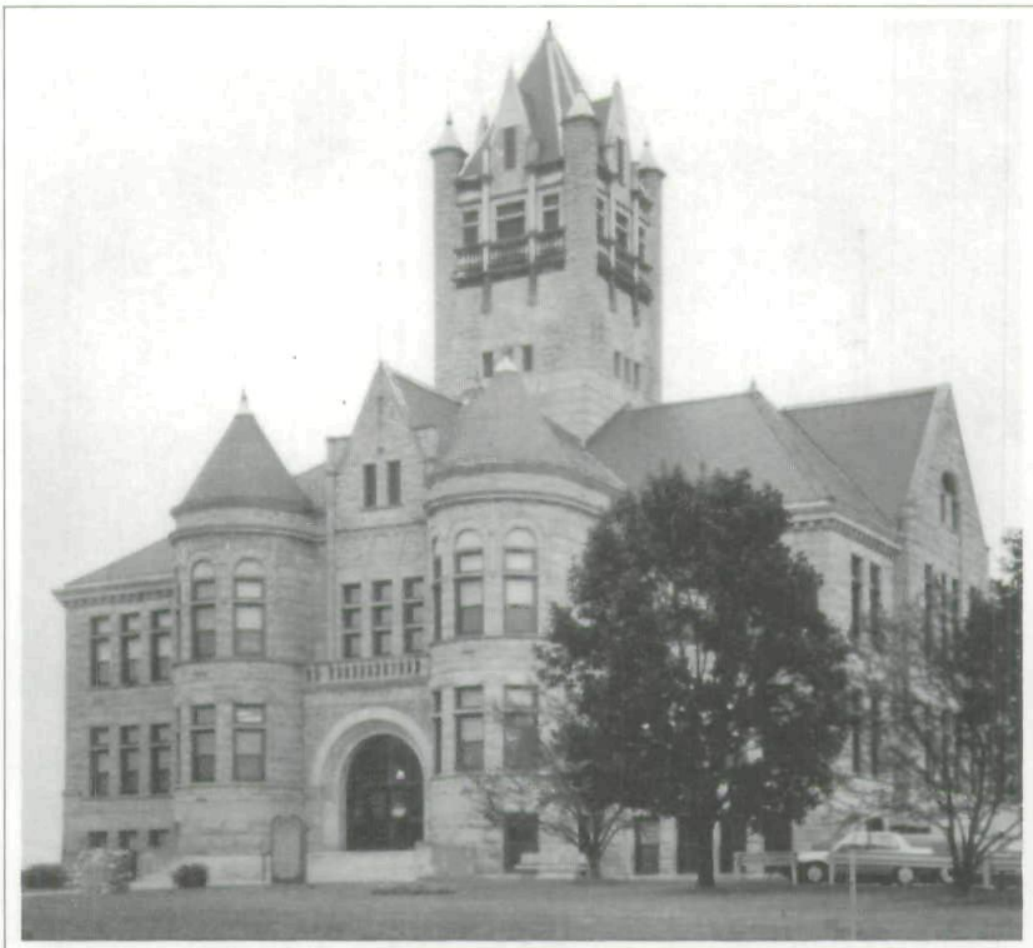

Fig. 2. Johnson County Courthouse, Iowa City, 1899-1901. Rush, Bowman and Rush. All photos by the author unless otherwise noted.

may, however, assume that what they built had their approval, and what they rejected did not. The buildings themselves, then, form a valid historic record of what the supervisors thought. Thus, to understand how the people of a particular state participated in the process of architectural change to create buildings that met their needs and reflected their society, we need to look more closely at the individual buildings they created.

FROM 1900 THROUGH 1929, twenty-eight Iowa counties built new courthouses in the American Renaissance style. The first sixteen of those buildings, built from 1900 through 1909, had towers; the remaining twelve did not. Of the courthouses with towers, five counties of smaller population-Clay, Plymouth, Osceola, Monroe, and Appanoose-have some of the earliest examples, dating from 1900 to 1903 . They form a transitional group because they retain certain architectural 




Fig. 3. Clay County Courthouse, Spencer, 1900-1901. Kinney and Detweiler. Photo from State Historical Society of Iowa, Iowa City.

characteristics of the preceding Romanesque Revival styles. For example, the Romanesque Revival buildings commonly used dark-colored, polychromatic building materials and rock-cut stonework. By contrast, one of the most striking characteristics of the American Renaissance style was its use of exterior walls of one shade of light-colored, smooth-surfaced stonework. Furthermore, the general symmetrical configurations of the transitional courthouses, with their central towers and hipped roofs, resemble those of the later Romanesque Revival courthouses, of which the Johnson County Courthouse in Iowa City is an example (fig. 2). The front of the building usually had a central portion projecting strongly and emphasized with its own roof. Sometimes additional smaller projections formed pavilions at the corners of the building, similarly emphasized by the roofs. Side and rear walls would be similar, but with a less impressive arrangement than the front.

The Clay County Courthouse in Spencer (1900) is a typical example of the transitional style (fig. 3). It carries over the dark wall colors characteristic of the earlier Romanesque Revival style, in this case red sandstone and two shades of brown brick. It has a visible roof and symmetrical massing. The front of the 


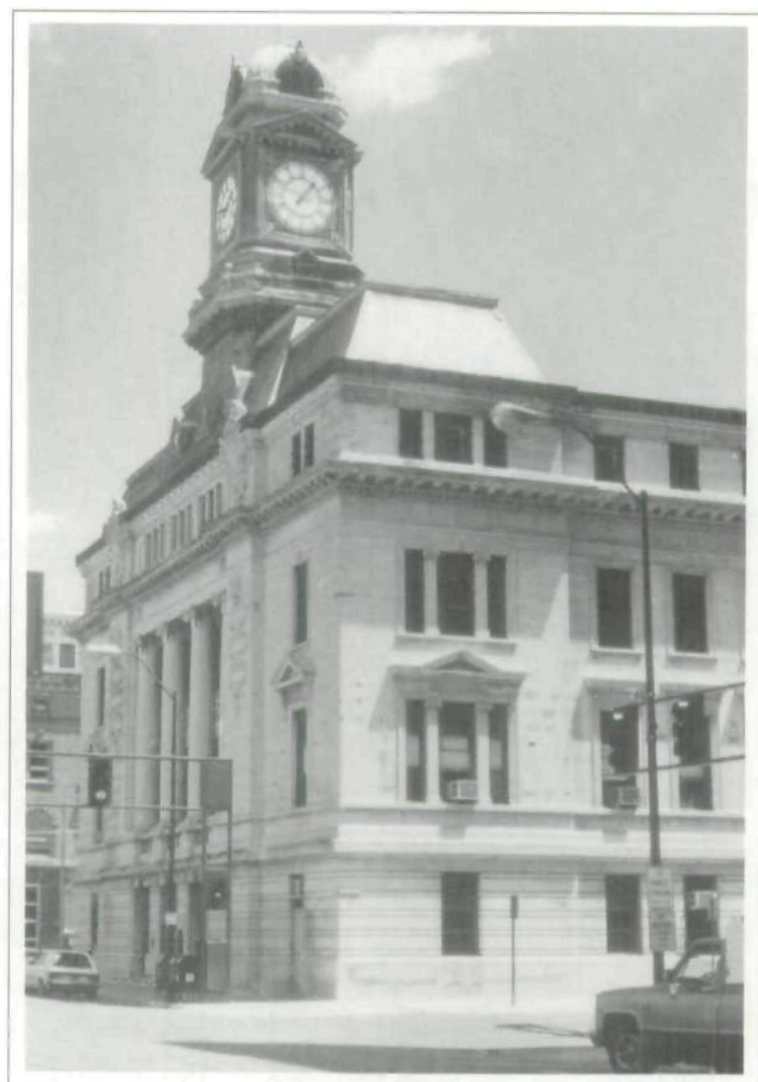

Fig. 4. Webster County Courthouse, Fort Dodge, 1901-1902. H. C. Koch \& Co.

building can be described as five-part pavilion massing, with a central pavilion consisting of a portico that projects strongly and is emphasized by a gable roof. The corners of the building have smaller pavilions with less projection that are topped by small, low domes. The sides and back of the building are similar to the front, but less impressive.

The three courthouses with towers built in more populous counties-Webster, Black Hawk, and Polk-were also built in the first three years of the century, but their designs, while showing considerable diversity, were architecturally more current and lacked transitional characteristics. The Webster County Courthouse (1901) in Fort Dodge is probably the most unusual, owing to its atypical downtown site (fig. 4). The tower 


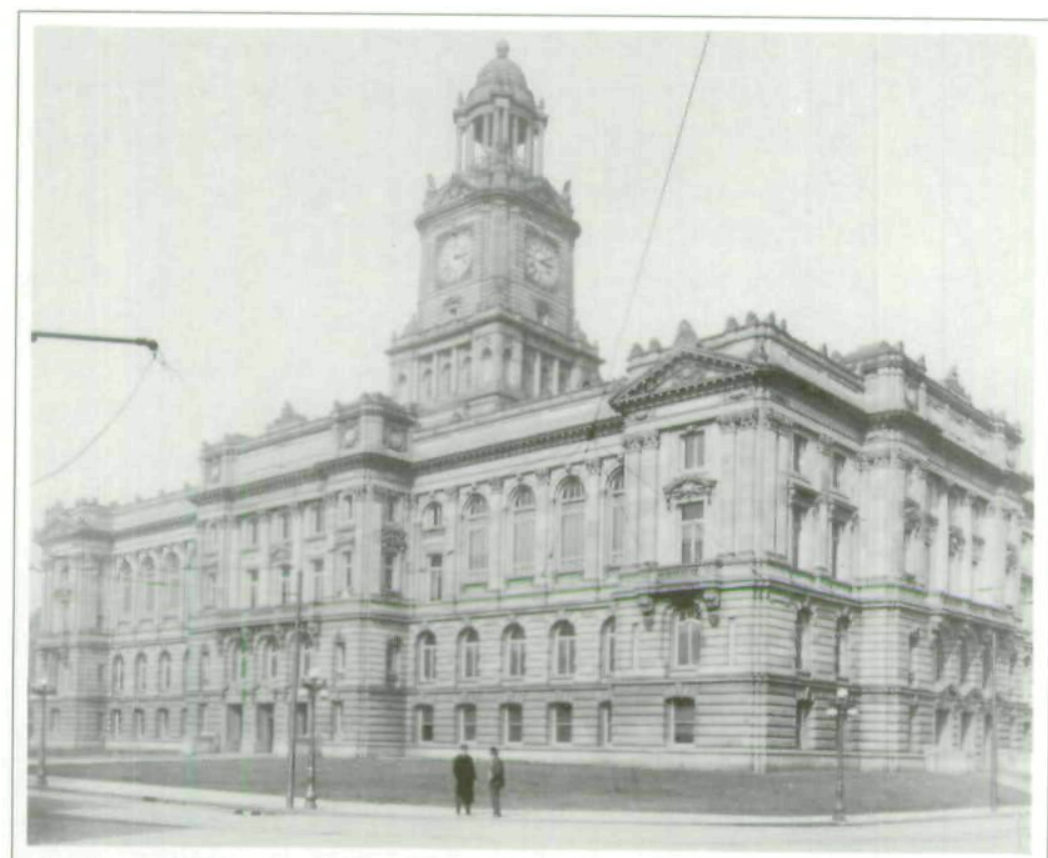

Fig. 5. Polk County Courthouse, Des Moines, 1902-1907. Proudfoot and Bird. Photo from State Historical Society of Iowa, Des Moines.

is at the front, rising from a decorative mansard roof, better to be seen from the nearby streets. In Waterloo, a central domed tower 116 feet tall dominated the Black Hawk County Courthouse (1901, razed 1966). Exterior photographs of the architect's rendering of the building showed walls of a darker color and architectural orders and decorative work of a more elaborate design than those features as built. ${ }^{11}$ The Polk County Courthouse in Des Moines (1902) is the largest of the three courthouses, taking up most of its downtown courthousesquare site (fig. 5). At its completion it was described as having "more floor space and greater length of corridor than any other building in the city outside of the capitol."12 It has five-part pavilion massing on the front similar to that of the Clay County

11. The renderings appear in the Waterloo Daily Courier, 12 June 1901, 6 August 1902. The photograph appears in Van Metre, History of Black Hawk County, 36.

12. "Polk County Courthouse," The Midwestern, pt. 4, vol. 1, no. 4 (1906), 57. 
Courthouse, but the roof is concealed, and the wall color is uniform and light, that of warm gray stone. All three have a BeauxArts character: Black Hawk as that style was interpreted in the late nineteenth century, and Webster and Polk as it was interpreted in the twentieth century. ${ }^{13}$

Eight other counties-Dallas (1901), Winneshiek (1903), Crawford (1903), Benton (1905), Decatur (1907), Muscatine (1907), Jasper (1909), and Keokuk (1909)—built courthouses with towers. The last of these, the Keokuk County Courthouse in Sigourney, has a visible roof, in that respect resembling the transitional courthouses such as the one in Clay County, but the roof is both hipped and gabled (fig. 6). It has three-part rather than five-part pavilion massing in front, with the central pavilion more complex than that at Des Moines. And its walls, like those of the Polk County Courthouse, are uniform and lightcolored.

Generally, the American Renaissance courthouses with towers retained several features from the late Romanesque Revival courthouses, most significantly the tower itself, which usually rose from the center of the roof. The towers often served a practical purpose. Sometimes they served as a belfry or clock tower. In the Greene County Courthouse of 1870, for example, the bell was used as a fire alarm, to call the court into session, and to announce curfew. ${ }^{14}$ The tower also served as a landmark and as a symbol of governmental power or purpose, often proclaimed by the statue of Justice. These same purposes

13. The architect of the Webster County Courthouse was H. C. Koch of Milwaukee, who also prepared the original Beaux-Arts design for the Black Hawk County Courthouse. The architect for the Black Hawk County Courthouse that was built was Fremont D. Orff of Minneapolis, who had designed several county courthouses in Minnesota. See David Gebhard and Tom Martinson, A Guide to the Architecture of Minnesota (Minneapolis, 1977), 169, $228,323,349$. The architects for the Polk County Courthouse were Proudfoot and Bird of Des Moines, the talented, dependable, professional designers of American Renaissance style buildings for state universities. See Barbara Beving Long, "Iowa's Pre-Eminent Architectural Firm: The Architectural Legacy of Proudfoot \& Bird, et al. in Iowa," typescript, Historic Preservation Bureau, State Historical Society of Iowa, Des Moines, 1987. Also of interest is Nancy J. Brcak and Jean W. Sizemore, "The 'New' University of Iowa: A Beaux-Arts Design for the Pentacrest," Annals of Iowa 51 (1991), 149-67.

14. E. B. Stillman, Past and Present of Greene County, Iowa (Chicago, 1907), 76. 




Fig. 6. Keokuk County Courthouse, Sigourney, 1909-1911. Wetherell and Gage.

carried over into the early twentieth-century courthouses. ${ }^{15}$ Nonetheless, the towers were later removed from the courthouses in Plymouth (1932), Crawford (1946), and Osceola (1961) counties. Often courthouse towers tended to leak, for it was hard to make them watertight, their materials weathered rapidly because of their exposure to the full force of the elements, and their height made repairs difficult.

The central tower, an important feature of Romanesque Revival courthouses, continued its visual role in the American Renaissance courthouses built in Iowa through 1909. There was an unsuccessful effort in Crawford County in 1903 to omit the tower to save money. In 1901 Black Hawk County rejected designs by architect H. C. Koch in which a dome would have replaced the tower. In the same year, Koch designed a tower for the Webster County Courthouse, which he even moved for-

15. Serving as a landmark was a strong argument for the proposed tower for the Linn County Courthouse, mentioned below. 


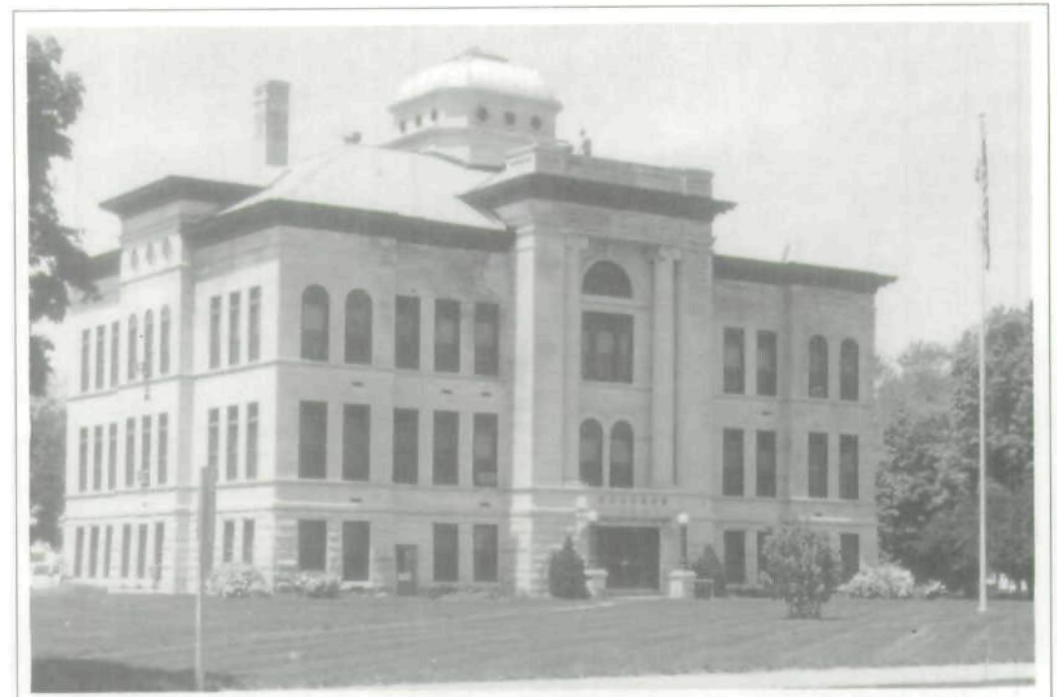

Fig. 7. Harrison County Courthouse, Logan, 1910-1911. J. E. Mills.

ward to make it more visible from the narrow streets nearby. But after 1909, no towers were built for Iowa's county courthouses. Cultural changes and architectural contradictions that became evident as the American Renaissance style developed contributed to the tower's demise. By 1915, a new, distinctive courthouse type had appeared. For this type, the tower was viewed as superfluous.

THE FIRST COURTHOUSES WITHOUT TOWERS otherwise differed little architecturally from those with towers. In fact, the first-the Harrison County Courthouse in Logan (1910) - merely replaced the tower with a small, shallow dome rising above the ridge of the roof (fig. 7). Three other courthouses were built prior to the full emergence of the new style in 1915: Henry County in Fairfield (1912), Calhoun County in Rockwell City (1913), and Greene County in Jefferson (1915). Although none has a central roof feature at all, they retained the pavilion massing and the alternatives of a visible or a concealed roof characteristic of the earlier courthouses with towers.

The final and distinctive type of courthouse without a tower first appeared in 1915. The O'Brien County Courthouse in Primghar was the first courthouse in Iowa to combine a con- 


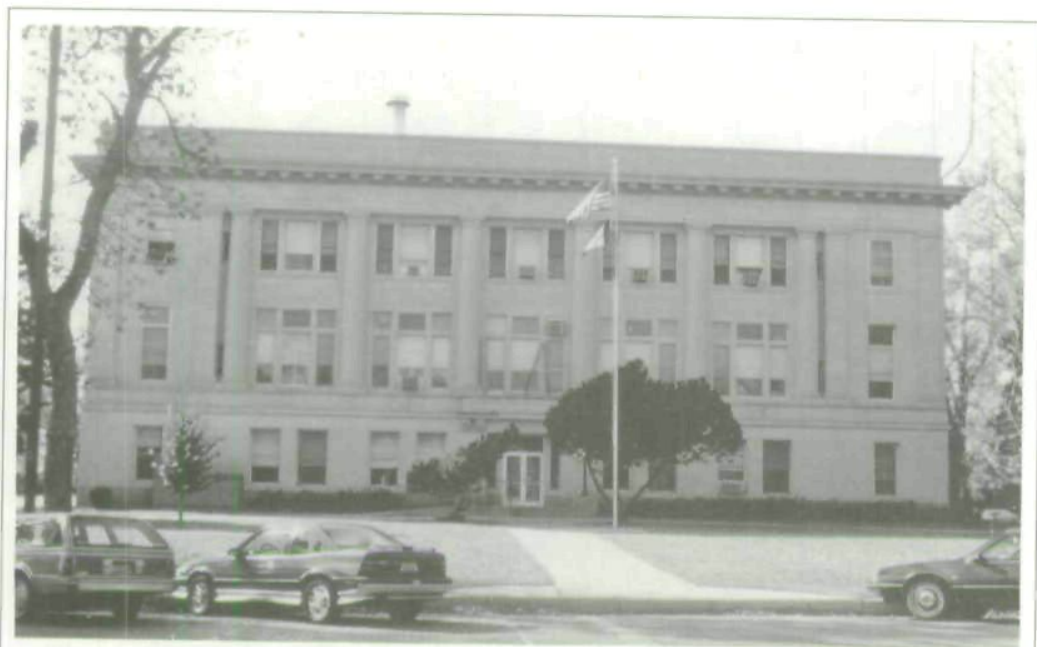

Fig. 8. O'Brien County Courthouse, Primghar, 1915-1916. Smith and Keffer.

cealed roof with colonnade massing and, of course, the absence of a tower (fig. 8). The building, which exemplifies Meeks's final phase, Picturesque Eclecticism, is substantially a simple block structure with colonnade recessed slightly between end pavilions. The front of the courthouse has a two-story colonnade placed on a basement story. The back is the same as the front, and the sides are flat. While the building was under construction, a Greene County newspaper published comments about it designed to convince citizens of that county to vote for a new courthouse. The O'Brien County Courthouse was variously described as "very simple in its outlines," "a modern adaptation of the Roman period of Classical architecture," and "having a rather stretchy longitudinal effect, fitting well with the flat prairie on which it is to be located, and being absolutely free from towers, turrets, or superfluous ornamentation." The article concluded noting the simplicity of the design and the convenience of its planning. ${ }^{16}$

In the Linn County Courthouse (1923), the largest of the courthouses without towers, the colonnade massing is more complex. The local newspaper described the exterior design as

16. Jefferson Bee, 15 May 1915. 




"the American adaptation of the Italian Renaissance style of architecture." The building was originally designed with a massive ornamental tower 150 feet tall (fig. 9). The supervisors, not following the usual sequence of events, had engaged their architect, Joseph Royer of Urbana, Illinois, to prepare preliminary designs in 1920, before the citizens had voted on issuing the bonds for construction. The citizens failed to approve a $\$ 1.3$ million bond issue late that year, but in 1922 they approved issuing bonds for $\$ 750,000$ to build the courthouse that we see today without a tower. Royer had said in 1920 that the tower could be omitted without changing the design of the building, for its purpose was only "making a striking and distinctive structure in place of the usual type of design." Since the courthouse site was opposite a large public square on a small island in the river that passed through the city, the separation from other tall buildings would make the courthouse tower "the most 


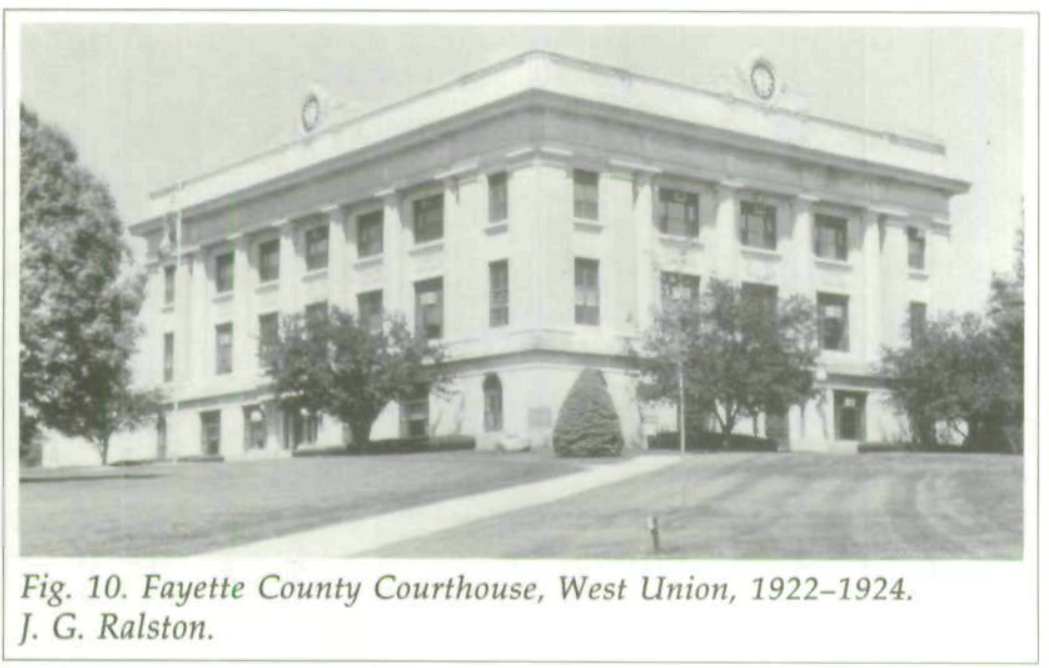

dominating feature in the city; and when illuminated by flood lighting at night [it] should be a landmark for the surrounding country." Royer also offered an option of adding thirty feet to the tower height to make it even more of landmark. However, in view of the citizens' vote, he revised his original design, removing the tower and the terraces at the front and sides that were created by a basement story wider than the main floor, its roof becoming a promenade terrace that softened the visual transition between building and site. ${ }^{17}$

The final, distinctive type comprises eight courthouses. In addition to those in $\mathrm{O}^{\prime}$ Brien and Linn counties, they were located in Lyon (1915), Boone (1916), Pocahontas (1921), Fayette (1922), Ringgold (1926), and Chickasaw (1929) counties. The colonnade, a characteristic feature of the final courthouse type, underwent a change in its architectural detailing among the later examples, from the use of the Greco-Roman architectural orders, as seen in the O'Brien and Linn County courthouses (figs. 8 and 9), to architectural orders in which column and pilaster capitals and bases were simplified, as seen in the Fayette County Courthouse in West Union (1922) (fig. 10). In addition, the structural system, hidden from view, achieved a high level of economical fireproof construction. By about 1915,

17. Proceedings of the Linn County Board of Supervisors, 1918-1923, pp. 203, 319, 340; Cedar Rapids Evening Gazette, 23 October 1920. 
efficient and economical reinforced-concrete construction had come into common use in the United States, and steel construction had been developed since the late nineteenth century. ${ }^{18}$

THE INTERIOR of Iowa's American Renaissance courthouses underwent a change that was as significant as the demise of the tower and the adoption of flat roofs and colonnade massing was for the exterior. The buildings usually had central lobbies at each story. In some of the early examples, large openings cutting through the floor between these lobbies created a central well of interior space. Daylight entered a skylight above the well and penetrated to the lower stories, as can be seen in the Lyon County Courthouse in Rock Rapids (1915) (fig. 11). In addition, the atrium provided a way to bring daylight into the heart of these courthouses. An atrium is a room two or more stories high with a skylight above it. Usually the surrounding corridors formed galleries overlooking the atrium. Like the well, it admitted daylight to the heart of the building, but its effect was more spacious. Sometimes the skylight was a small circular opening, or oculus, in a dome; in other cases the skylight was a flat or a domed glass ceiling. Sometimes, too, an atrium was placed above a well, as at the Jasper County Courthouse in Newton (1909) (fig. 12). Wells had appeared in some nineteenth-century courthouses in Iowa, and in twentieth-century courthouses both the well and atrium were used, but the atrium was more characteristic of the later examples. Of the sixteen courthouses with towers, ten have a well or an atrium; of the twelve courthouses without towers, only one lacks such an interior space.

Beneath the tower of the Black Hawk County Courthouse (1901), a tall rotunda rose to a domed ceiling with an oculus of prism glass to create "a splendidly lighted interior." A newspaper description, written when the building was accepted, called the light amber, dark red, and green of the rotunda decorations the most striking of any in the building. A bronze casting of Chief Black Hawk, like that over the west entrance, hung above the entrance to the east corridor, and the rotunda and all of the

18. Carl W. Condit, American Building Art: The Twentieth Century (New York, 1961), 158. 


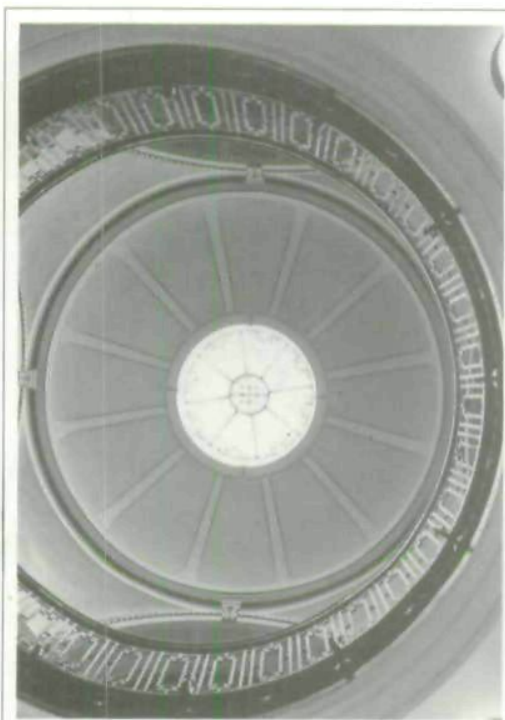

Fig. 11. Lyon County Courthouse interior llooking up toward skylight), Rock Rapids, 1915-1917. Joseph Schwartz.

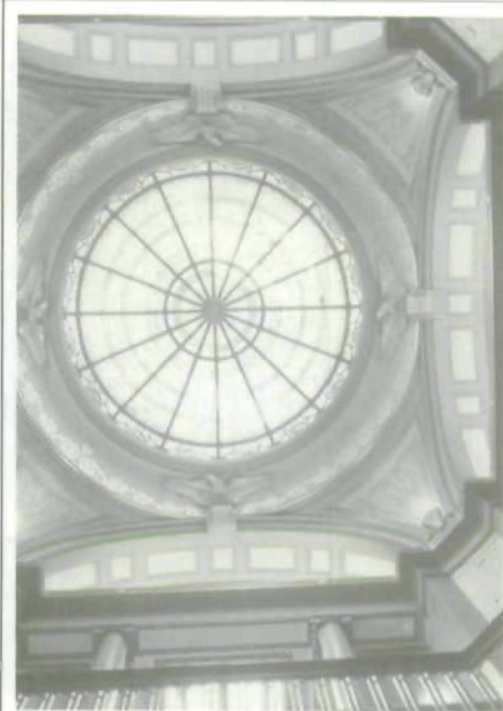

Fig. 12. Jasper County

Courthouse interior llooking up toward skylight), Newton, 1909-1911. Proudfoot and Bird.

main corridors were of white marble. ${ }^{19}$ Beneath the tower of the Polk County Courthouse (1902), a two-story atrium and the two-story well beneath it form a rotunda that is covered by a domed ceiling with an oculus. The spacious, skylighted stairwells at either side of the rotunda join it to create a vast, multistory open space of impressive dimensions (fig. 13). The dedication ceremonies were held there, with the public gathering on the balconies and looking at the crowds below. ${ }^{20}$

The Boone County Courthouse in Boone (1916) is the one example of the eight final courthouses that lacks an atrium or well. An earlier design for it had such a space. In 1915 the supervisors were ready to sign a contract with Falls City Construction Company of Louisville, Kentucky, for a courthouse constructed according to the company's plans and specifications. The local newspaper reported, "The general plan of the building with regard to inside arrangements is somewhat simi-

19. Waterloo Daily Courier, 6 August 1902.

20. Des Moines Register and Leader, 31 October, 1 November 1906. 


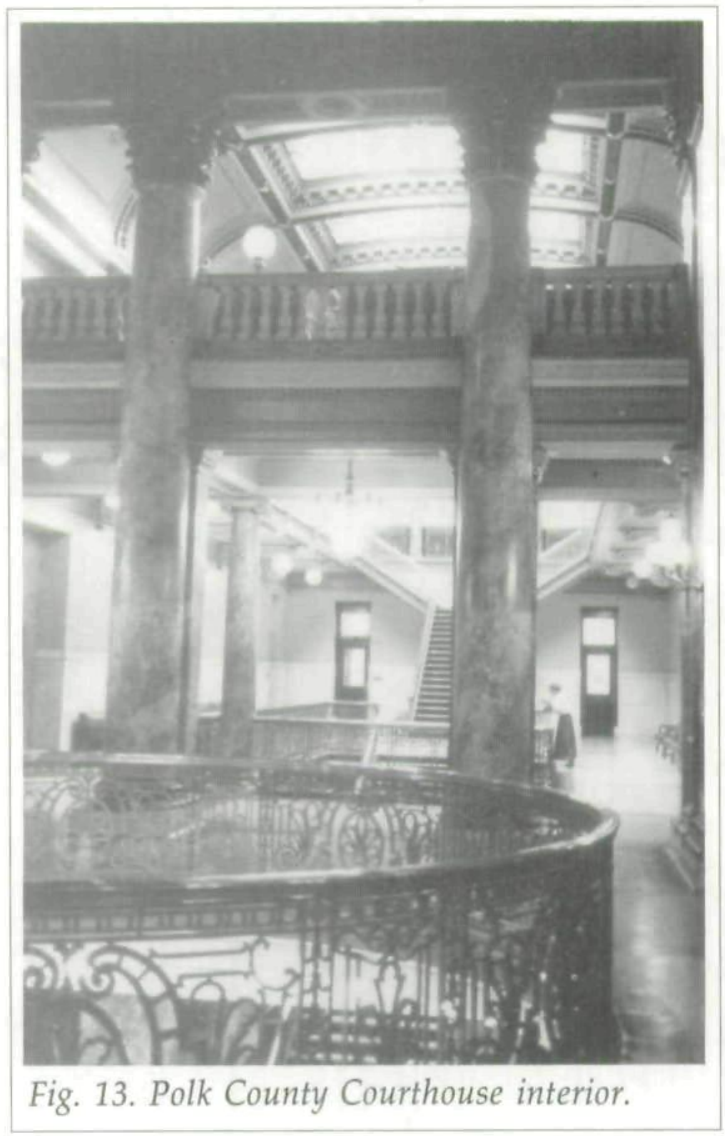

lar to the state capitol building, that of a rotunda on the first floor and the open space reaching to the top of the building with the broad stairs leading up from each floor at the back of the building." A drawing of the exterior of the building shows that it was square in plan, doubtless to provide the depth needed to accommodate the square central space. This design was not built. Legal and other expert opinions caused the board to reject all bids. The fact that the design appears to have been prepared by the low-bidding contractor may have been at the heart of the legal difficulties, although Calhoun County had successfully followed such a procedure with the same contractor a few years earlier. After the initial design was rejected, the Boone County supervisors engaged Norman T. Vorse of Des Moines as their architect, and he prepared a new design. Sev- 
eral letters to a local newspaper in 1913 observed that a courthouse was not a civic ornament but "a place for business, quiet business"; that moving to a downtown location was justified for convenience; that a courthouse adds nothing to a park (that is, the old courthouse-square site), nor a park to a courthouse; and that a courthouse is "the biggest business house in the county $\ldots$ in which a larger volume of business is transacted than in any other building in the county." ${ }^{21}$ Utilitarian views such as these must have been held by the supervisors when the building was designed in 1916. In order to save money they omitted the atrium and rebuilt on the old courthouse square site several miles from downtown.

Otherwise, all of the courthouses without towers had a well or an atrium or both. The combination of well and atrium in the Greene County Courthouse in Jefferson (1915), similar to the central space of the Jasper County Courthouse, was recognized at the time of its dedication as a pleasing and practical feature serving as a light shaft and as a way to reach all offices directly. ${ }^{22}$ While residents of Greene County were making plans for their own courthouse, the local newspaper described the atrium of the O'Brien County Courthouse, then under construction. "An interesting feature of the interior is an open well in the center of the building about fifteen feet square, extending from the court room story and finished with an arched steel dome, inlaid with artistic patterns of glass, affording a flood of light for these two stories, and creating an imposing and interesting architectural interior." 23 The skylighted atrium of the Linn County Courthouse is much more spacious, as would be expected in a much larger building (fig. 14). The central, taller portion, which would have been beneath the tower, is lighted by clerestory windows; the portions at each side, by skylights. The atrium of the Pocahontas County Courthouse in Pocahontas (1921) (fig. 15) is depicted in the county history as a "rotunda, which is magnificent in grandeur and beauty, with its

21. Boone News-Republican, 18 November 1915; Boone County Supervisors Record, vol. 6, pp. 411, 420, 421; Boone County Democrat, 31 July, 21 August 1913.

22. Jefferson Bee, 31 October 1917.

23. Jefferson Bee, 15 April 1915. 


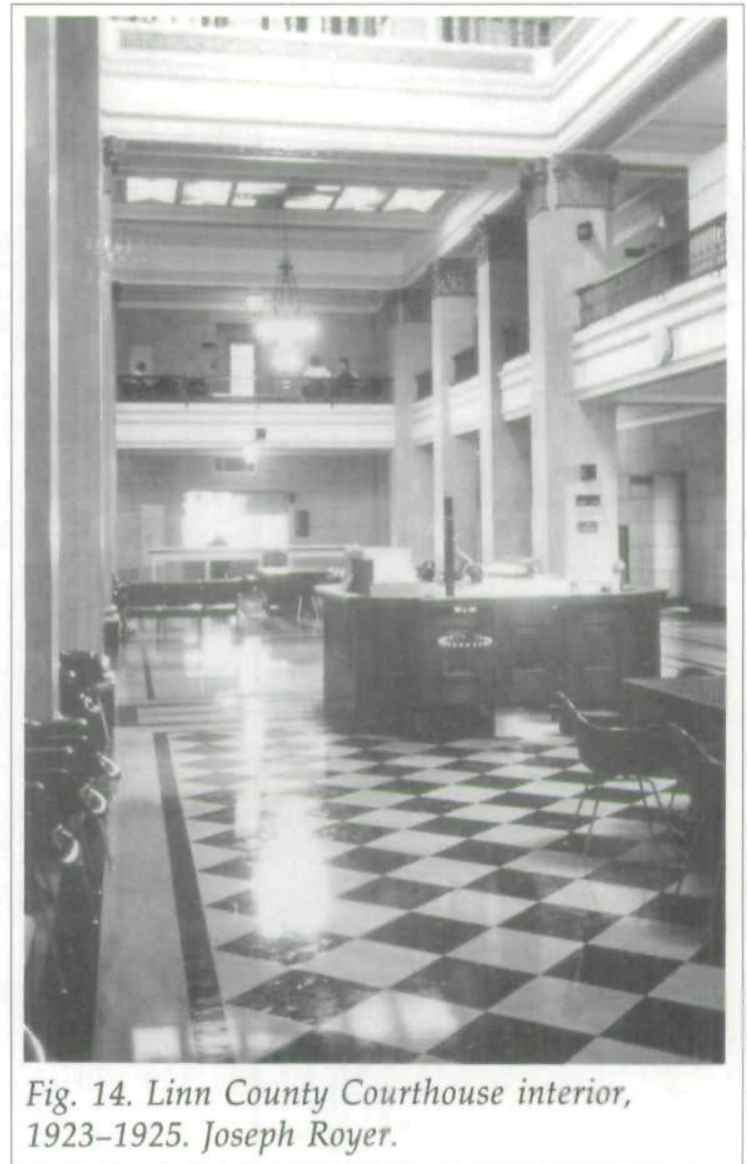

pillars and pilasters. It forms the center of the building from which you enter the several offices and rooms of the structure. Looking upward for sixty feet one is entranced with the columns and walls decorated with marble and gold, tinted with the most pleasing effects. The art glass of the dome gives an abundance of light." 24 The writer of the dedication booklet for the Fayette County Courthouse (1922) offered briefer comments about the atrium in that building (fig. 16). "On ascending to the third floor, you find yourself in the Rotunda looking down on the floor below and up to the art glass dome above, which is indeed beautiful in construction and finish." 25

24. Pocahontas County, Iowa, History (Rolfe, 1982), 10.

25. Souvenir Booklet, Fayette County Courthouse (Arlington, 1923), 15. 


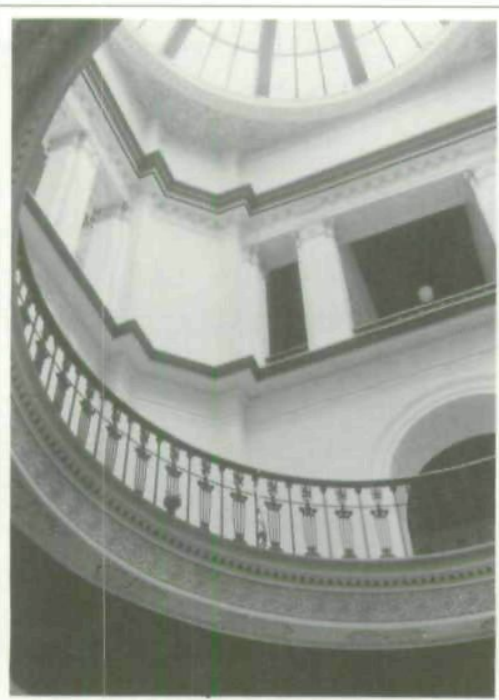

Fig. 15. Pocahontas County Courthouse interior (looking up toward skylight), 1921-1923.

Proudfoot, Bird and Rawson.

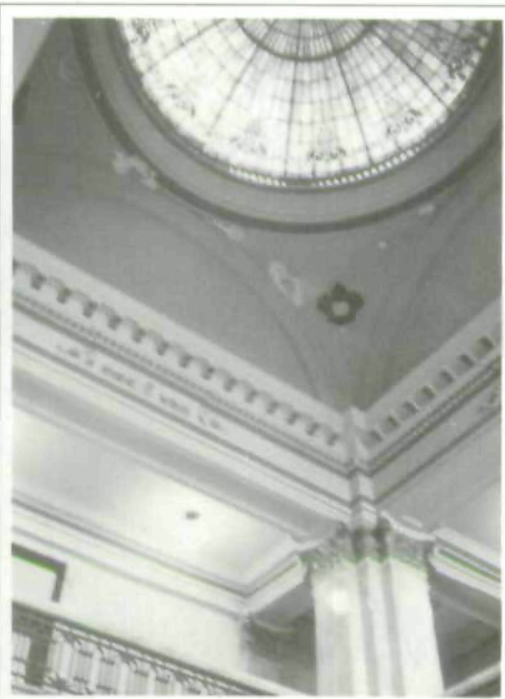

Fig. 16. Fayette County Courthouse interior (looking up toward skylight).

These changes in the interior of the courthouses came about partly as the result of an architectural inconsistency directly related to the demise of the courthouse tower. Thus, the interior changes were also an integral part of the architectural changes that were associated with a change in the meaning of the county courthouse itself. The domed tower, which is the form of fourteen of the sixteen courthouse towers of this investigation, may be interpreted as a symbol of governmental power, because it looks like a more slender version of the dome on a drum characteristic of American state capitols and the national capitol. In the capitols, however, the dome is the structure spanning a wide rotunda, while in county courthouses, the tower with dome may lack a well or an atrium below it, as is the case with the tower of the Crawford County Courthouse. The problem lies in the architectural ambiguity of the domed tower. In resembling the capitol dome, it suggests a rotunda below it. To the extent that it resembles a solid-looking tower, such a tower seems inappropriate poised above the openness of a rotunda. Probably the open, domed towers of the Clay, Plymouth, Osceola, and Benton county courthouses cope best with 
the double identity because of their openness, which helps them provide the maximum daylight for the skylight or oculus. However, when the skylighted central atrium became an architectural goal in itself-and the extensive descriptions of them found in the newspapers of the period suggest their considerable importance-a tower rising above the atrium skylight became unnecessary, and it interfered with the entrance of daylight. The demise of the courthouse tower, then, reflects architectural logic and the abandoning of the nineteenthcentury purposes-belfry, clock tower, symbol, and landmark-which were at odds with the new meaning and importance of the atrium. ${ }^{26}$

THE VISUAL IMPACT of two characteristic American Renaissance courthouses illustrates the cultural and architectural change that took place in the early decades of the twentieth century. The Clay County Courthouse of 1901 (fig. 2) stands in the center of a courthouse square two blocks west of the town's main street. The site is level. The surrounding houses set off the larger scale of the building. The classical main entrance portico with its two-story columns is raised a half-story above the ground, making an impressive ceremonial entrance. When the building was new, citizens would have found its classical architectural detailing new, orderly, and simple, compared to the Romanesque Revival detailing with which they were familiar, yet the reds and browns of the building would have been reassuringly similar to the older style, along with the general mass-

26. Similar connections between courthouse architecture and governmental change certainly may exist in other states. The best evidence of architectural similarities in the buildings would be the fact that fourteen of the twentyeight American Renaissance courthouses in Iowa were designed by eight outof-state architectural firms from Minnesota, Wisconsin, Illinois, Michigan, Nebraska, and South Dakota, and a construction company in Kentucky. Minnesota firms designed six buildings dating from 1900 to 1905; from each of the other states only one or two firms designed a courthouse. A review of The County Court Houses of the United States: The Seagram County Court House Archives and Other Photographic Collections in the Library of Congress (Essex, NY, 1981) showed similarities in the architecture but differences in dates of construction from those in Iowa. This source, however, is a random collection of material, so it can give only general indications. Governmental developments would have to be studied in each state in order to establish the parallels. 
ing, as seen in the Johnson County Courthouse (fig. 1) and others of its time. Tower, dome, and clock are still present in the Clay County tower, symbols of county importance. Inside the building, one finds a spacious central lobby on the first and second floors connected by a wide stairway. There is no well or skylight, but the tower with its open sides suggests an original skylight. Remodeling in 1981 may have removed it, and possibly a well also. The Plymouth County Courthouse, a similar building by the same architects, had a well and skylight.

The O'Brien County Courthouse (fig. 8) created a very different impression for the citizens who first used it. It too stands in a level public square in the midst of the downtown, but people walked into it directly through a generous but unceremonial entrance. The colonnade of its facade, the counterpart of the portico of the Clay County Courthouse, is integrated into the overall pattern of the building block. The structure's greatest dimension is its width, not its height. The impression lacks the architectural symbols of authority-the tower and the ceremonial entrance portico and stairway. The colonnade massing groups a large number of windows at the second and third stories, suggesting many rooms of similar importance at these floors. The treatment of the basement level shows that its rooms are less important than those above. Exterior display of authority is absent. The newer building reserves what display it has for the interior. Citizens entered and mounted a wide staircase to the main floor and a two-story atrium covered by a domed skylight of prismatic glass. The corridors of the building form galleries around the atrium, borrowing light from it. The bright atrium provides a visual focus for the whole interior.

The Clay County Courthouse was still a temple of justice; the O'Brien County Courthouse had become something more. In the early years of the twentieth century many new bureaucratic activities came to be housed in Iowa courthouses along with the earlier judicial activities. The authoritative connotations of the tower were no longer appropriate for the Progressive Era, in which government came to be viewed as an up-todate social institution that worked to serve people's needs, not to control them. ${ }^{27}$ Thus in Iowa the towered courthouse was

27. Today many courthouses have a steel, microwave-radio tower on the roof 
replaced after 1909, and a new courthouse type appeared in 1915. This new type adopted a new architectural symbol-the atrium-which was perceived from within the buildings instead of from without. The atrium expressed the notion that the courthouse was more than just an office building but was a place where people could come together. It symbolized community and democracy and a sharing of power. ${ }^{28}$ The atrium became the interior architectural equivalent of the public square in which all but one of the courthouses stood. ${ }^{29}$ Thus, the courthouse ceased to be the temple of justice that it had been in the nineteenth century and became a government office building for the people. The tower was the symbol associated with the old courthouse; the atrium with the new.

or nearby on the site (see fig. 8), an unintended landmark and a technological upgrading of the courthouse bell.

28. Charles T. Goodsell, The Social Meaning of Civic Space: Studying Political Authority through Architecture (Lawrence, KS, 1988) 29.

29. American courthouse squares orginated in Pennsylvania and Tennessee in the late 1700 s and early 1800 s. See Edward T. Price, "The Central Courthouse Square in the American County Seat," in Common Places: Readings in American Vernacular Architecture, ed. Dell Upton and John Michael Vlach (Athens, GA, 1986), 125-33. 
Copyright of Annals of Iowa is the property of State of Iowa, by \& through the State Historical Society of Iowa and its content may not be copied or emailed to multiple sites or posted to a listserv without the copyright holder's express written permission. However, users may print, download, or email articles for individual use. 